\title{
ESOTERISMO E FILOSOFIA POLÍTICA NA OBRA DE L. STRAUSS
}

\author{
Richard Romeiro Oliveira \\ Universidade Federal de São João Del-Rey
}

\begin{abstract}
Resumo: 0 presente artigo pretende abordar a questão das relações essencialmente conflituosas entre filosofia e sociedade na obra de Leo Strauss, buscando mostrar de que maneira, segundo esse autor, o conflito mencionado torna a atividade filosófica uma atividade politicamente problemática e perigosa, 0 que obriga o filósofo, num contexto de perseguição, a lançar mão de uma técnica literária específica - a escrita esotérica -, no intuito de ocultar a problematicidade política da filosofia, apresentar uma versão moralmente edulcorada de sua atividade e dirimir, assim, o seu antagonismo em relação à ordem social vigente. $O$ artigo procurará também, a partir disso, explicitar como, na óptica straussiana, o uso da escrita esotérica como procedimento destinado a apaziguar o conflito entre filosofia e sociedade se confunde, originalmente, com a própria filosofia política, entendida como "apresentação política da filosofia".
\end{abstract}

Palavras-chave: Filosofia Política, Esoterismo, Sociedade, Lei Divina, Strauss.

\begin{abstract}
This article aims to approach the issue of essentially conflictual relations between philosophy and society in the work of Leo Strauss, seeking to show how, according to this author, the mentioned conflict makes philosophical activity a politically problematic and dangerous one, which forces the philosopher in a persecution context to resort to a specific literary technique - the esoteric writing - in order to hide the political problematicity of philosophy, to present a morally sweetened version of its nature and so to settle its antagonism with the prevailing social order. From that, the article will also seek to explain how, in the Straussian view, the use of esoteric writing as a procedure to ease the conflict between philosophy and society is originally identified with the political philosophy itself, which is understood as "political presentation of philosophy".
\end{abstract}

Keywords: Political philosophy, Esotericism, Society, Divine Law, Strauss.

\section{Introdução}

Autor de uma obra densa e provocativa, Leo Strauss é um dos pensadores contemporâneos cuja influência, no contexto atual, mais cresce e se desenvolve, exercendo um impacto inegável e poderoso nos meios acadêmicos e intelectuais da América do Norte (Estados Unidos e Canadá) e de certos países da Europa continental (França e Alemanha, principalmente). Com efeito, nas regiões mencionadas, o pensamento de Strauss tornou-se, desde algum tempo, o objeto central de candentes debates filosóficos e políticos, alimentando intensas polêmicas e discussões, tanto nos círculos 
estritamente universitários quanto no espaço da mídia highbrow e culturalmente mais sofisticada. ${ }^{1}$ Analisando tal fenômeno no contexto do mundo norteamericano, a estudiosa canadense Drury avança, a propósito, em seu trabalho The Political Ideas of Leo Strauss (2005, p.1), as seguintes e pertinentes considerações: "não há nenhum exagero em dizer que o impacto de L. Strauss sobre a comunidade acadêmica norte-americana é um fenômeno. Ele é o fundador de um movimento, de uma escola de pensamento e mesmo de um culto"2. Trata-se aí, devemos desde já frisar, de um fenômeno dotado de extraordinária importância, que faz jus à riqueza e ao alcance genuinamente reflexivo dos textos de Strauss e que dissipa definitivamente a visão hermeneuticamente equivocada que por muito tempo prevaleceu acerca do significado de sua obra, visão que impedia que os trabalhos straussianos obtivessem o reconhecimento filosófico que lhes é inequivocamente devido. De fato, é sabido que L. Strauss foi muitas vezes observado como um mero erudito especializado no comentário dos textos do passado ou da tradição, como um simples scholar cuja produção intelectual, encontrando-se substancialmente presa ao âmbito convencional da historiografia das ideias, nada apresentaria, portanto, de instigante ou de original, do ponto de vista propriamente filosófico. ${ }^{3}$ Porém, pode-se considerar que tal perspectiva erra completamente o alvo no que diz respeito à compreensão da verdadeira natureza dos textos de Strauss, não atinando para a peculiaridade que lhes é inerente. Strauss, realmente, está longe de ser um simples scholar ou historiador

${ }^{1}$ Cf., sobre isso, PANGLE (2006, p.1-6).

2 A obra de Drury deve ser lida, porém, cum grano salis, pois, apesar de tratar Strauss como um verdadeiro filósofo ("Strauss", diz ela na p. 4 do livro mencionado, "is an important philosopher worthy of careful study and criticism") e de conter valiosos insights e esclarecimentos sobre o alcance filosófico dos seus textos, é francamente hostil no que diz respeito ao suposto maquiavelismo déguisé do pensamento político straussiano, desenvolvendo toda uma diatribe contra o hipotético impacto desse maquiavelismo sobre o movimento neoconservador norte-americano e sobre aquela que foi a principal expressão de tal movimento no terreno propriamente público e governamental: os métodos agressivos implementados pela administração G. W. Bush no campo das relações internacionais. Uma avaliação crítica dessa perspectiva hermenêutica e de sua contribuição para a consolidação da equivocada imagem midiática de Strauss como eminência parda e mentor maquiavélico por trás do neoconservadorismo que inspirou os rumos da política externa desenvolvida pelo governo de G. W. Bush pode ser encontrada em ZUCKERT, C.; ZUCKERT, M. (2006, p.1-23). Ver também, sobre 0 assunto, MÉNISSIER (2009, p.873-893).

${ }^{3}$ Como observa Drury (2005, p.3-4): "Strauss is not generally regarded as a philosopher, but as a scholar and a historian of ideas. This is understandable, for he was a most prolific writer on the history of political thought. His most famous books include Persecution and the Art of Writing, Natural Right and History, Thoughts on Machiavelli, The City and Man and On Tyranny. All his books and most of his articles are commentaries on the great political philosophers of the past, even when this is not made obvious by the titles." Ver também, sobre isso, o que diz BLOOM (1974, p.376), MÉNISSIER (2009, p.873) e ZUCKERT, C.; ZUCKERT, M. (2006, p.1). 
ortodoxo e, compulsando de forma mais atenta e cuidadosa seus textos, percebemos que eles apresentam um caráter insólito, excêntrico e profundamente inquietante, na medida em que combinam, com grande maestria e raro virtuosismo exegético, os recursos próprios do comentário histórico mais rigoroso com o desenvolvimento de uma reflexão pessoal, profunda, sofisticada e filosoficamente provocadora. Temos nesse elemento, sem dúvida alguma, um dos traços mais marcantes da démarche metodológica exercitada magistralmente por Strauss, a qual consiste na tentativa de suscitar indagações e questionamentos verdadeiramente filosóficos, a partir da leitura meticulosa e obstinadamente paciente das grandes obras que nos foram legadas pelos melhores e mais brilhantes espíritos do passado. ${ }^{4} \mathrm{~A}$ aposta straussiana subjacente à realização dessa démarche parece ser a de que o trabalho historiográfico consagrado à filosofia, desde que efetuado com propósitos genuinamente reflexivos e não meramente arqueológicos, i. e., desde que efetuado de maneira pensante e com o intuito de levar a sério a pretensão dos autores antigos de transmitirem um ensinamento verdadeiro em suas obras, pode se converter em um elemento apto a nos conduzir ao âmbito de uma investigação de caráter propriamente filosófico, extrapolando os limites de uma pesquisa meramente erudita e desencadeando em nós a experiência decisiva das questões mais profundas e fundamentais - questões que não são de forma alguma meramente históricas ${ }^{5}$. É meditando provavelmente nessa possibilidade de um uso filosófico da história do pensamento que Strauss nos fornece, em sua obra Philosophy and Law (1995, p.41), a seguinte e esclarecedora afirmação: "Não há nenhuma investigação no interior da história da filosofia que não seja, ao mesmo tempo, uma investigação filosófica".

Strauss crê, portanto, na possibilidade de uma apropriação filosófica da história da filosofia. Isso significa que, para ele, o estudo dos textos do passado, desde que filosoficamente motivado, nada tem de inócuo ou de meramente acadêmico, mas constitui, antes, um procedimento fecundo e mesmo necessário para aqueles que pretendem adentrar o registro diferenciado

\footnotetext{
${ }^{4}$ Cf. BLOOM (1974, p.376-377); PANGLE (2006, p.7).

${ }^{5}$ Ver STRAUSS (1996, p.324-325) e os ótimos esclarecimentos de Sedeyn, em sua apresentação da tradução francesa de The City and Man (STRAUSS, 2005, p.26-30). Cf. igualmente as seguintes observações de Ménissier (2009, p.876): "Repositionner l'œuvre de Strauss dans le champ philosophique qui est authentiquement le sien promet un gain substantiel. En effet, on pourrait dire que les « îlots » constitués par ses grands ouvrages d'histoire de la philosophie sont reliés en archipel par une intention philosophique commune et par une intuition puissante : Strauss s'est tourné vers l'histoire de la philosophie politique pour des raisons philosophiques de fond et, surtout, selon un mode qui évoque finalement le style des philosophes de l'Antiquité - délaissant l'actualité pour chercher la vie juste et digne dans le cadre d'un enseignement de type socratique."

${ }^{6}$ Todas as traduções dos textos de Strauss citadas neste artigo são de minha autoria.
} 
do pensamento genuinamente filosófico. Radicalizando essa proposta metodológica, Strauss chegará a considerar que a leitura reflexiva e pensante das grandes obras pertencentes à tradição filosófica representa, no atual momento de crise e decadência intelectuais em que nos encontramos imersos, um medium privilegiado graças ao qual podemos aceder à genuína experiência da atividade filosófica, rompendo momentaneamente com os preconceitos e dogmas que dominam o nosso tempo e que vedam nosso acesso à experiência original da filosofia. ${ }^{7}$ É o que se vê claramente, por exemplo, a partir desta sua lapidar formulação:

Nós não podemos ser filósofos, mas nós podemos amar a filosofia; nós podemos tentar filosofar. Filosofar consiste inicialmente e, de um certo modo, principalmente, em ouvir a conversação dos grandes filósofos ou dos grandes espíritos e, por conseguinte, em estudar os grandes livros 8 .

Pois bem, no interior de sua sofisticada reflexão - que mescla, como dissemos acima, os recursos próprios da erudição histórica mais sólida com a ousadia intelectual inerente ao questionamento autenticamente filosófico -, Strauss concede um espaço destacado à abordagem de uma questão que, em sua perspectiva, possui uma relevância decisiva no contexto da filosofia política tradicional, área à qual o autor dedicou, como é sabido, uma boa parte de sua rica produção bibliográfica. Tal questão, para dizer tudo sem maiores delongas, diz respeito ao caráter politicamente problemático da filosofia no seio da sociedade, ou, por outra, à natureza essencialmente perturbadora e mesmo perigosa da filosofia em face da ordem moral e comunitária da pólis, elemento que resulta diretamente, segundo nosso autor, das relações complexas e conflituosas que o exercício da racionalidade filosófica entretém originalmente com o funcionamento ordinário da vida política e com os valores e as crenças que lhe dão sustentação. Para Strauss, temos aí, sem dúvida alguma, um fenômeno realmente crucial para se compreender a posição inicialmente anódina e subversiva da filosofia no interior do corpo social, fenômeno que nos desvelaria como a filosofia, em suas origens, é um empreendimento intelectual que nada tem de inofensivo, apresentando-se, antes, como uma atividade insólita e incômoda, que "põe em risco a

\footnotetext{
${ }^{7}$ Remetemos o leitor, aqui, mais uma vez, às boas observações de BLOOM (1974, p.376-377). 8 Cf. STRAUSS, 1989, p.7. Conferir também, sobre 0 assunto, o que o filósofo desenvolve no ensaio "What is Liberal Education?", contido na coletânea An Introduction to Political Philosophy (in STRAUSS, 1989, p.311-320), e também o que ele diz em sua obra clássica Persecution and the Art of Writing (1992a, p.157-158). Para um breve comentário desse aspecto do pensamento straussiano, ver OLIVEIRA (in CARDOSO, 2012, p.23-25), juntamente com as considerações elaboradas por TANGUAY (2003, p.11-12).
} 
sociedade", sendo, por isso, "suspeita para a maioria". Uma das ambições fundamentais da obra straussiana consiste em analisar como esse fenômeno se apresenta em sua significação mais radical, primeva e originária, no mundo antigo e medieval, no intuito de recuperar o aspecto primordialmente problemático e excepcional da filosofia, tal como ele se apresenta anteriormente aos desenvolvimentos engendrados pelo pensamento iluminista moderno, que, buscando justamente suprimir, de uma vez por todas, a oposição entre filosofia e sociedade por meio de um projeto de politização ou popularização radical e sem precedentes do ensinamento filosófico, acabou por vulgarizar a filosofia e degradá-la à condição de mera dóxa no mercado da opinião pública ${ }^{10}$.

Mas isso não é tudo: segundo Strauss, a abordagem do tema da problematicidade política da filosofia, mediante a compreensão do antagonismo originário entre a filosofia e a sociedade, nos conduz inexoravelmente ao enfrentamento da questão das relações da filosofia com a lei divina, ou, por outra, da filosofia com a religião, desembocando, consequentemente, naquilo que Strauss chama de "problema teológicopolítico". Segundo a visão straussiana, tal é assim porque no âmbito das sociedades tradicionais, i. e., no âmbito das sociedades alheias às transformações históricas produzidas pelo iluminismo moderno, os valores e crenças responsáveis pela manutenção do ordenamento político e social sempre foram apresentados como mandamentos sagrados, mandamentos estes que, encontrando nos deuses ou na ação daqueles que se apresentavam como arautos dos deuses sua fonte primordial, garantiam para a ordem comunitária o seu esteio ético e axiológico mais fundamental ${ }^{11}$. Em outras palavras, em todas as comunidades pré-modernas, o ensinamento religioso e a lei divina a ele associada funcionaram sempre como as instituições sociais basilares, como o cimento da moralidade comunitária, por assim dizer, e, no caso do Ocidente, em particular, é sabido que a revelação bíblica e o ensinamento teológico nela

${ }^{9}$ Cf. STRAUSS (1988, p.221); STRAUSS (1971, p.143).

${ }^{10}$ Acerca do esforço presente na obra de Strauss para recuperar a dimensão politicamente problemática da filosofia e, por aí, o caráter excepcional e insólito da atividade filosófica, contra a "vulgarização" da filosofia operada pelo pensamento moderno, leiam-se os excelentes esclarecimentos de Sedeyn (in STRAUSS, 2005, p.33-34). Sobre a crítica de Strauss à modernidade, ver os comentários de FERRY (1999, p.53-72) e MÉNISSIER (2009, p.877-879).

11 Cf., sobre isso, o que Strauss diz em The City and Man (1992b, p. 240-241). No que tange às relações entre política, moralidade e religião em Strauss, vejam-se os seguintes e valiosos esclarecimentos de Drury (2005, p.37): "The conflict between philosophy and society has its origin in the fact that philosophy cannot rationally justify the two things on which society rests: morality and religion. For Strauss these two are not separate. Morality has its source in law, and the latter cannot elicit the respect and the obedience of the many if it is not believed to have divine origin. Strauss follows the Judaic and Islamic tradition in conceiving the religion in terms of Sacred Law." 
presente exerceram, por séculos, o papel de fundamento precípuo de toda ordem e de toda civilização. Pensar o fenômeno da problematicidade política da filosofia, mediante uma reflexão sobre o caráter conflituoso das relações da filosofia com a sociedade política, requer, pois, necessariamente, na elaboração straussiana, o desenvolvimento de uma reflexão acerca do confronto da filosofia com a lei divina, e, levando em conta o fato de que o mundo ocidental foi, por séculos, marcado pela profunda influência política e social exercida por tradições religiosas que se pretendem oriundas de uma palavra divina revelada (a Bíblia), uma análise das relações entre filosofia e revelação, ou, como Strauss gostava de dizer, entre Atenas e Jerusalém ${ }^{12}$.

A proposta fundamental do presente artigo consiste em compreender como se dá a articulação desses elementos na reflexão levada a efeito por Strauss, evidenciando de que maneira, segundo este autor, a filosofia política nada mais foi, a princípio, do que a tentativa de dirimir o antagonismo originário entre a filosofia e a sociedade num plano retórico e discursivo, graças à elaboração de um procedimento literário diferenciado - a técnica da escrita esotérica -, capaz de fornecer uma apresentação edulcorada ou politicamente aceitável da filosofia diante da cidade e efetuar, assim, a compatibilização do exercício do pensamento filosófico com a ordem e com os valores da vida cívica. Tal é a tarefa que nos propomos a realizar na sequência de nosso texto.

\section{O caráter politicamente problemático da filosofia: a filosofia como busca da natureza das coisas e como rebelião intelectual contra a autoridade política do ancestral e da tradição}

Pode-se dizer que o pensamento de Strauss tem como um de seus móveis precípuos a tentativa de efetuar uma reflexão sistemática e paciente acerca do significado originário da filosofia política, i. e., acerca do caráter da filosofia política tal como ela se apresenta em suas origens no mundo clássico e medieval, anteriormente às transformações históricas e intelectuais produzidas pelo desenvolvimento modernidade. Para Strauss, tal tarefa teórica se revestiria, nos dias de hoje, de uma importância crucial e decisiva, sobretudo por duas razões fundamentais: por um lado, porque a filosofia política, em virtude do triunfo acadêmico de determinadas correntes intelectuais como o historicismo e o positivismo, se encontraria, atualmente, em estado de evidente declínio e ameaçada de extinção, sendo amiúde tolerada apenas como uma peça de museu no contexto de estudos de caráter meramente histórico ou

12 Acerca do problema teológico-político em Strauss, cf. TANGUAY (2003, p.223-293); MEIER (2006, p.3-28). 
erudito; por outro lado, porque a efetivação de uma reflexão consistente sobre o significado e o estatuto da filosofia política seria justamente aquilo que falta aos grandes pensadores da época contemporânea (Bergson, Whitehead, Husserl, Heidegger), os quais negligenciaram as questões cruciais que estão em jogo no âmbito dessa disciplina ${ }^{13}$. Analisando as obras de Strauss, percebemos, porém, que ele parece considerar que a realização da tarefa teórica acima enunciada não é algo simples, mas um procedimento reflexivo complexo, que pressupõe como tal, necessariamente, a confrontação e a adequada compreensão de duas questões preliminares e de caráter fundamental, quais sejam: 1) a questão da determinação da natureza da filosofia em geral, i. e., da identificação do tipo de comportamento intelectual colocado em ato pelo exercício da atividade filosófica, de vez que a filosofia política nada mais é que um ramo da filosofia ${ }^{14}$, e 2) a questão da compreensão de qual é o impacto desse comportamento intelectual próprio da atividade filosófica sobre o funcionamento da sociedade política ou da vida civil. Ora, explorando com grande argúcia essas questões, Strauss acaba por nos mostrar o caráter visceralmente problemático das relações da filosofia com a sociedade política, evidenciando o fato de que, via de regra, o exercício da racionalidade filosófica tem um efeito perturbador e corrosivo sobre a normalidade cívica e a ordem moral vigente.

O ponto de partida da investigação de Strauss acerca desses temas é o entendimento de que a filosofia, em sua expressão mais autêntica e originária, consiste, antes de tudo, numa atividade impulsionada por um desejo apaixonado e audacioso: o desejo do conhecimento do todo e de suas causas desejo que, elevando os pensamentos do filósofo às alturas da ordem eterna, fá-lo observar os elementos meramente humanos como derrisórios, efêmeros e insignificantes ${ }^{15}$. A partir dessa formulação, a reflexão straussiana considera

13 É o que Strauss afirma explicitamente em um de seus textos mais conhecidos, intitulado What Is Political Philosophy? (1988, p.17): "Today, political philosophy is in a state de decay and perhaps of putrefaction, if it has not vanished altogether [...] The only point regarding which academic teachers still agree, concerns the usefulness of studying the history of political philosophy. As regards the philosophers, it is sufficient to contrast the work of four greatest philosophers of the last forty years Bergson, Whitehead, Husserl and Heidegger - with the work of Hermann Cohen in order to see how rapidly and thoroughly political philosophy has become discredited." Sobre esse tema em Strauss, ver as elucidações de ZUCKERT, C.; ZUCKERT, M. (2006, p.31). Cf. também, desses mesmos autores, o artigo "Leo Strauss et le problème de la philosophie politique" (in COPPENS; JANSSENS; YOMTOV, 2014, p.15-24) e o que diz PANGLE (2006, p.41-46).

14 Nas palavras de Strauss, presentes na obra acima mencionada (1988, p.10-11): "Since political philosophy is a branch of philosophy, even the most provisional explanation of what political philosophy is cannot dispense with an explanation, however provisional, of what philosophy is."

15 Cf. as seguintes considerações elaboradas por Strauss na obra On Tyranny (2013, p.198): "The philosopher's dominating passion is the desire for truth, i. e., for knowledge of eternal order, or the eternal 
então que a filosofia, por ser mobilizada pelo desejo do conhecimento do todo, envolve, assim, necessariamente a procura de um saber universal ou totalizante, i. e., a procura de um saber acerca de Deus, do mundo e da natureza humana, o qual, precisamente por não se encontrar originalmente à disposição de nossa razão, justifica e torna necessária a atividade intelectual da filosofia. Ora, como Strauss nos faz ver, a ausência inicial de um conhecimento universal ou da totalidade, que justifica e torna necessária a atividade intelectual da filosofia, não significa que os homens não possuam, antes do advento da filosofia, pensamentos acerca do todo. Pelo contrário, pode-se dizer que desde os primórdios os homens formularam crenças acerca do universo, ou, por outra, crenças acerca das primeiras coisas, dos deuses e de si próprios, o que nos mostra que a filosofia é sempre precedida pela opinião. Ora, se a filosofia é a busca do saber acerca do todo e se a opinião, enquanto primeira articulação forjada pelo pensamento humano para alcançar uma compreensão da totalidade, é aquilo que antecede cronológica ou historicamente a filosofia, percebe-se, então, que a filosofia, como atividade intelectual, consiste, pois, essencialmente, "na tentativa de transformação das opiniões acerca de 'todas as coisas' em conhecimento acerca de 'todas as coisas"'. Nas palavras do próprio Strauss:

Filosofia, como busca da sabedoria, é a busca do conhecimento universal, do
conhecimento do todo. A busca não seria necessária se tal conhecimento se
encontrasse imediatamente disponível. A ausência do conhecimento do todo
não significa, contudo, que os homens não tenham pensamentos acerca do
todo: a filosofia é necessariamente precedida pelas opiniões acerca do todo. A
filosofia é, portanto, a tentativa de substituir opiniões acerca do todo pelo
conhecimento do todo. Em vez de "todo", os filósofos também dizem "todas as
coisas": o todo não é um puro éter ou uma treva irremediável na qual não se
pode distinguir uma coisa da outra, ou na qual não se pode discernir nada. A
busca do conhecimento de "todas as coisas" significa busca pelo conhecimento
de Deus, do mundo, do homem - ou, antes, busca pelo conhecimento da
natureza de todas as coisas: as naturezas em sua totalidade são "o todo" (1988,
p.11).

Strauss, porém, julga que a filosofia, apesar de ser impulsionada pelo desejo audacioso do conhecimento do todo, pelo eros que ambiciona a consecução de um saber onímodo e universal, capaz de apreender a verdade acerca da ordem eterna, não pode se converter plenamente em ciência do todo. Com efeito, nosso autor faz questão de frisar, num espírito evidentemente socrático, que a filosofia é não a posse da verdade, mas a sua procura, de forma que o traço distintivo do filósofo é que ele "sabe que nada sabe"

cause or causes of the whole. As he looks up in search for the eternal order, all human things and human concerns reveal themselves to him in all clarity as paltry and ephemeral [...]". 
(STRAUSS, 1988, p.11). Isso significa, em última análise, que a posse cabal do conhecimento universal não está ao alcance de nosso intelecto e que a filosofia, portanto, jamais poderá deixar de ser uma procura - a procura erótica e incansável da sabedoria. E a razão disso, segundo ele, encontra-se na própria finitude do homem: com efeito, enquanto parte do todo, o homem é marcado por uma limitação constitutiva, o que torna sua capacidade cognitiva ou epistêmica de entendimento sempre parcial e restrita. Ora, na medida em que o entendimento humano é sempre finito, a totalidade guarda, assim, para o homem, um caráter radicalmente misterioso e enigmático, um caráter de insuperável incompreensibilidade. ${ }^{16}$ Isso faz com que a filosofia seja afetada por um inacabamento e por uma problematicidade essenciais, o que determina que em seu âmbito a evidência das questões ou das perguntas suscitadas pela atividade reflexiva seja sempre maior que a evidência das soluções ou das respostas elaboradas. Strauss sintetiza esses elementos da seguinte forma:

A filosofia, no significado original do termo, nada mais é do que conhecimento
da própria ignorância [...]. O que Pascal disse com uma intenção antifilosófica
sobre a impotência do dogmatismo e do ceticismo é a única justificação possível
da filosofia, que, como tal, não é dogmática nem cética, muito menos
"decisionista", mas zetética (ou cética, no sentido original do termo). A filosofia
como tal nada mais é que a genuína consciência dos problemas, i. e., dos
problemas fundamentais e abrangentes. É impossível pensar acerca desses
problemas sem se inclinar para uma ou outra das poucas soluções típicas.
Porém, na medida em que não há sabedoria, mas apenas busca da sabedoria, a
evidência de todas as soluções é menor que a evidência dos problemas.
Consequentemente, um filósofo deixa de ser filósofo no momento em que sua
'certeza subjetiva' quanto a uma solução torna-se mais forte do que sua
consciência do caráter problemático dessa solução. Neste momento, nasce um
sectárión ${ }^{17}$.

Tocamos aqui um ponto fundamental do pensamento de Strauss, a saber: sua visão da natureza fundamentalmente zetética da filosofia, visão fundada no reconhecimento da finitude do entendimento humano e que envolve a concepção da atividade filosófica mais como um exercício de pesquisa, mobilizado pela consciência de nossa ignorância diante do caráter misterioso do todo e dos problemas fundamentais a ele relacionados, do que como a elaboração de sistemas ou de doutrinas cujos ensinamentos conteriam respostas definitivas e peremptórias para as questões mais profundas que

${ }^{16}$ Cf. STRAUSS (1988, p.38-39). Para um comentário acerca dessa questão na obra straussiana, ver as observações de TANGUAY (2003, p.276-278).

17 Cf. 2013, p. 196-197. A respeito do caráter problemático e, por conseguinte, zetético da filosofia, ver igualmente as seguintes reflexões desenvolvidas por Strauss em seu artigo "The Mutual Influence of Theology and Philosophy" (1979, p.113): "Philosophy is quest for knowledge regarding the whole. Being essentially quest and being not able to become wisdom, as distinguished from philosophy, the problems are always more evident than solutions." 
assolam nosso pensamento. Tanguay chama a nossa atenção para a importância realmente crucial desse elemento teórico na reflexão straussiana, ao avançar as seguintes considerações: "Este reconhecimento de uma limitação radical do poder do intelecto é um princípio fundamental e constante do pensamento de Strauss. É preciso levar a sério suas numerosas declarações acerca do caráter inacabado da filosofia"18. Conforme mostra Strauss, a constatação dos limites cognitivos e epistêmicos da razão humana diante do mistério do todo e da problematicidade radical das questões fundamentais, desembocando, consequentemente, na admissão do caráter essencialmente inacabado da empresa filosófica, não desqualifica a filosofia ou torna vão e supérfluo o seu exercício: pelo contrário, segundo ele, em sendo verdadeiramente "conhecimento da nossa ignorância" e não meramente ignorância, a filosofia nos traz uma compreensão sempre mais aprofundada, rica e aguda das questões fundamentais e dos assuntos a elas concernentes, compreensão que é muito superior e mais valiosa do que quaisquer conhecimentos que possamos ter em relação à multidão das questões secundárias ou de somenos importância. Como Strauss esclarece, numa elaboração lapidar:

Filosofia não é a posse da verdade, mas a procura da verdade. O traço distintivo do filósofo é que ele "sabe que nada sabe" e é esta sua percepção de nossa ignorância no que concerne às coisas mais importantes que o induz a lutar com todas as suas forças pelo conhecimento. Ele deixaria de ser um filósofo fugindo às questões relativas a essas coisas ou negligenciando-as porque elas não podem ser respondidas. Pode ser que a respeito das possíveis respostas a essas questões os prós e os contras estarão sempre em um equilíbrio mais ou menos constante e que, portanto, a filosofia jamais vá além do estágio da disputa, não alcançando o estágio da decisão. Isso não tornaria a filosofia fútil. Pois a clara compreensão de uma questão fundamental requer o entendimento da natureza do assunto a que ela se refere. O conhecimento genuíno de uma questão fundamental, mediante o seu entendimento, é melhor que a cegueira ou indiferença em relação a uma questão fundamental, seja essa indiferença ou cegueira acompanhada pelo conhecimento ou não das respostas a um vasto número de questões periféricas ou efêmeras ${ }^{19}$.

${ }^{18}$ Cf. TANGUAY, 2003, p.277. Leiam-se, também, em relação à concepção anti-dogmática e zetética da filosofia proposta por Strauss, os bons esclarecimentos de ZUCKERT, C.; ZUCKERT, M. (2006, p.8587).

${ }_{19}$ Cf. 1988, p.11. Conferir também as seguintes observações de Strauss em: "Reason and Revelation (1948)" (in MEIER, 2006, p.147-148): "Philosophy stands or falls by the possibility of suspense judgement regarding the most fundamental questions. That is to say, philosophy is as such sceptical: in the original meaning of the term. Sképsis means looking at things, considering things. Philosophy is concerned with understanding reality in all its complexity. Its complexity may preclude demonstrative answers to the fundamental questions: the arguments in favor of the various incompatible answers may be inconclusive. This would not make philosophic enterprise futile: for the philosopher, full understanding of a problem is infinitely more important than any mere answer". 
Pois bem, por ser um procedimento zetético, mobilizado pela consciência de nossa ignorância diante das questões fundamentais e que procura substituir opiniões acerca do todo pelo conhecimento do todo, tendo em vista, no limite, a consecução de um saber onímodo e universal acerca da totalidade, a filosofia envolve, para Strauss, uma vida de livre investigação, o que pressupõe o exercício de um questionamento audacioso, vertiginoso e radical, que não se detém diante de nada ou de ninguém (nem mesmo diante daquelas coisas consideradas como mais sagradas e veneranda) e que é capaz de arrastar o filósofo para além da dimensão política, religiosa e moral convencional ${ }^{20}$. Nesse sentido, Strauss afirma que a filosofia, como comportamento cognitivo, nada tem a ver com a moderação ou com a temperança; ao revés, seu exercício envolve uma espécie de visceral desmesura intelectual, uma forma de loucura, de intemperança ou de impudência, próxima da embriaguez. "A moderação não é uma virtude do pensamento", diz-nos ele, neste sentido; "Platão vincula a filosofia à loucura, o oposto mesmo da sobriedade ou da moderação; o pensamento não deve ser moderado, mas destemido (fearless), para não dizer despudorado (shameless)" (STRAUSS, 1988, p.32). Ora, vê-se bem, a partir desses elementos, que a filosofia, para Strauss, não é uma prática inócua ou inofensiva, mas, antes, uma atividade intelectual perigosa e politicamente problemática, de forma que suas relações com a ordem social só podem ser, a princípio, relações incômodas e de caráter conflituoso ${ }^{21}$. Com efeito, Strauss entende que se a filosofia é a tentativa de transformar opiniões em conhecimento, por meio da prática radical do questionamento mais ousado e destemido, e se "a opinião é o elemento mesmo da sociedade", pode-se dizer que o exercício da filosofia é intrinsecamente subversivo e iconoclasta, na medida em que ele implica a tentativa de "dissolver o elemento da sociedade" - algo que, evidentemente, coloca em risco a normalidade cívica e a estabilidade do éthos comunitário ${ }^{22}$. Em outras palavras, o questionamento filosófico, envolvendo a assunção de

20 Cf. STRAUSS (apud MEIER, 2006, p.147); STRAUSS (1979, p.111-112).

21 Ver os esclarecimentos de TANGUAY (2003, p.118).

22 É o que Strauss deixa totalmente claro em "Reason and Revelation (1948)" (apud MEIER, 2006, p.146): "Philosophy as the quest for the true beginnings of all things is the attempt to replace opinions about these beginnings by genuine knowledge, or science, of them. Now, it is by no means certain that this is a legitimate pursuit. Not only was there a popular prejudice against the attempt at prying into the secrets of the gods, but reasons suggested the view that opinion, and not knowledge, is the very element of human or social or political life. If opinion is the element of the political life, philosophy which questions opinions as such, dissolves the very element of social life: philosophy is essentially subversive (corrupting the young)". Essa mesma ideia é retomada por nosso autor em What Is Political Philosophy? (1988, p.221). 
um posicionamento intelectual de caráter crítico e francamente heterodoxo em face das crenças autorizadas que sustentam a moralidade vigente, ofende a ordem política instituída e pode ser visto assim, inicialmente, como um elemento altamente nocivo e perturbador para a estrutura comunitária, o que engendra inevitavelmente um conflito ou antagonismo entre a filosofia e a sociedade, tornando manifesta a problematicidade política originária da atividade filosófica ${ }^{23}$.

Em seu clássico estudo Natural Right and History, Strauss explicita como essa subversão intelectual perpetrada pela filosofia em relação às opiniões autorizadas que sustentam a ordem política e social foi possibilitada originalmente pela descoberta revolucionária da ideia de natureza. Para tornar isso manifesto, Strauss remonta às épocas mais arcaicas da história e parte da observação de que, antes do aparecimento da filosofia, no contexto das sociedades tradicionais, o bom era identificado essencialmente com o ancestral, vale dizer, com a lei tida como a mais vetusta, prístina e multissecular, cuja origem, portanto, se perdia misteriosamente na noite abissal dos tempos. $\mathrm{O}$ ponto fundamental para o qual Strauss chama a nossa atenção nesse momento de sua reflexão é o fato de que, nas referidas sociedades, a crença predominante era de que a lei vigente e os preceitos por ela estatuídos, que determinam o modo correto de viver (the right way), eram reverenciados como bons porque eram vistos como os mais antigos, a antiguidade funcionando, assim, nesse registro pré-filosófico, como um critério capaz de conferir prestígio e venerabilidade aos códigos instituídos, donde a célebre máxima latina citada por Strauss: vetustas semper pro lege habetur (1971, p.83). Porém, a análise straussiana nos mostra imediatamente que isso é verdadeiro apenas em parte. Com efeito, dando sequência à sua reflexão, Strauss observa que a mera antiguidade, por si só, não é realmente um critério suficiente para fornecer a um código respeitabilidade intrínseca e autoridade inquestionável: antes, para que um código adquira essas características, ele precisa ser tido não apenas como o mais antigo, como o mais vetusto, mas também como algo dotado de caráter divino, i. e., como algo que remonta sua gênese à ação exemplar dos deuses ou dos filhos dos deuses ou, pelo menos, dos homens que tiveram um contato privilegiado com os deuses: o modo correto de viver deve ser, assim, resultado de uma lei divina (STRAUSS, 1971, p.83-84; 1979, p.111).

Ora, a filosofia, na formulação straussiana, surge justamente como descoberta da ideia de natureza (phýsis, na terminologia grega), por oposição ao

${ }^{23}$ É o que ressalta Drury (2005, p.19): "Philosophy offends the city because it questions the opinions on which the city is based. Those who offend the citizens are likely to be ridiculed, persecuted or destroyed. Socrates is a case in point". Ver também as observações de PANGLE, 2006, p.54-56. 
que é meramente ancestral e à lei tida como divina. Seguindo essa linha de raciocínio, Strauss chega mesmo a afirmar, com ênfase especial, a existência de uma radical interdependência entre esses dois fenômenos - o aparecimento da filosofia e a descoberta da natureza -, ressaltando que ambos os eventos se encontram intrinsecamente vinculados entre si, de forma que não devemos esperar o conhecimento da categoria de natureza (que será a base precípua de todas as teorias do direito natural) onde não há a experiência intelectual da filosofia. Strauss nota oportunamente, neste sentido, que a Bíblia hebraica não possui um termo que corresponda adequadamente à noção de natureza: a Bíblia hebraica, diz-nos ele, fala apenas de "céus e terra", mas tal expressão não pode ser identificada à concepção de "natureza" como tal:

A ideia de direito natural deve permanecer desconhecida enquanto a ideia de natureza for desconhecida. A descoberta da natureza é obra da filosofia. Onde não há filosofia, não há nenhum conhecimento do direito natural como tal. $\mathrm{O}$ Velho Testamento, cuja premissa básica pode ser considerada a rejeição da filosofia, não conhece a natureza. O termo hebraico para natureza é desconhecido na Bíblia hebraica. Não é preciso dizer que "céus e terra", por exemplo, não é a mesma coisa que "natureza" 24 .

O elemento que possibilitou essa inovação foi, segundo Strauss, a constatação (feita, inicialmente, por viajantes experientes e homens que conheceram muitos povos) da multiplicidade dos códigos ancestrais que vigoram nas mais variadas formas de sociedade, a constatação, pois, da multiplicidade das leis divinas. A partir dessa constatação, o pensamento humano se dá conta, então, das profundas divergências existentes entre os diferentes códigos e leis, não somente no que diz respeito às questões morais e aos costumes, mas também no que diz respeito às explicações acerca das "primeiras coisas", i. e., no que diz respeito às narrativas cosmogônicas. Ora, apoiando-se nessa identificação e lançando mão da diferenciação, originalmente percebida no terreno das técnicas e das artes manuais, entre o que deve sua origem à ação humana e o que não deve sua origem à ação humana (ou que existe por si), a filosofia descobre o caráter radicalmente artificial ou convencional daquilo que é determinado pelos múltiplos códigos divinos e parte, mediante o desenvolvimento de uma audaciosa empreitada intelectual, em busca daquilo que é bom, justo e verdadeiramente primeiro não mais de acordo com as leis e convenções instituídas por esta ou aquela

${ }^{24}$ Cf. STRAUSS, 1971, p.81. Vale registrar que em "Reason and Revelation (1948)" (apud MEIER, 2006, p.145) Strauss já observara: "What separates the philosopher from the mythologist, is the discovery of physis: the first philosopher was the discoverer of phýsis. Physis had to be discovered: man does not know without further ado that there is such a thing as nature". 
sociedade, mas em si mesmo ou por si mesmo, vale dizer, por natureza (STRAUSS, 1971, p.86-90).

Ora, para Strauss, a descoberta da ideia de natureza assim entendida, operada pelo exercício da reflexão filosófica, possibilitando a interrogação acerca do que é bom, justo e primeiro por si mesmo, em oposição ao que é bom, justo e primeiro por mera convenção ou artifício social, altera radicalmente a relação do homem com a autoridade. De fato, partindo em busca da verdade acerca das primeiras coisas e do que é bom e justo por si mesmo, a filosofia pretende ir além do ancestral, no intuito de alcançar um princípio mais originário e mais antigo do que qualquer lei ou tradição ancestral: a natureza. Com isso, a filosofia abala profundamente a autoridade da sociedade política e o prestígio das leis que a sustentam, de vez que, como se viu, esses elementos repousam in toto sobre a crença no caráter venerando e sagrado da ancestralidade. Conforme explana Strauss:

A emergência da filosofia afeta radicalmente a atitude do homem em relação às
coisas políticas, em geral, e em relação às leis, em particular, porque ela afeta
radicalmente seu entendimento dessas coisas. Originalmente, a autoridade par
excelence ou a raiz de toda autoridade era o ancestral. Por meio da descoberta da
natureza, a pretensão do ancestral é subvertida: a filosofia apela do ancestral
para o bom, para o que é intrinsecamente bom, para o que é bom por natureza.
No entanto, a filosofia subverte a pretensão do ancestral de tal maneira que
preserva um elemento que lhe é essencial. Pois, ao falar da natureza, os
primeiros filósofos queriam dizer as primeiras coisas, i. e., as coisas mais antigas;
a filosofia apela do ancestral para alguma coisa mais antiga do que o ancestral. A
natureza é mais antiga do que qualquer tradição; por isso, ela é mais venerável
do que qualquer tradição ${ }^{25}$.

A filosofia irrompe, pois, como busca da natureza das coisas e, por conseguinte, como um questionamento radical e audacioso da autoridade da lei ancestral e da tradição, manifestando-se como uma capacidade de transcender o dado histórico que envolve necessariamente uma rebelião intelectual contra aquilo que goza do mais alto prestígio na sociedade (FERRY, 1999, p.73-74). É justamente isso que explica, na formulação straussiana, o caráter essencialmente subversivo e perturbador da filosofia ${ }^{26}$, atividade cujo modus operandi pressupõe necessariamente uma contestação intransigente daquilo que confere a uma determinada ordem política e social sua venerabilidade e sua mais preciosa fundamentação moral. Ora, na medida em que, segundo Strauss, como vimos, a autoridade da lei ancestral em que se incorporam as opiniões

${ }^{25}$ Cf. 1971, p. 91-92. A mesma concepção reaparece no artigo "The Mutual Influence of Theology and Philosophy" (1979, p.111-112).

26 "Philosophy is essentially subversive (corrupting the young)", diz Strauss em "Reason and Revelation (1948)" (apud MEIER, 2006, p.146). 
autorizadas de uma sociedade tradicional depende da crença no caráter sagrado dessa lei, i. e., do fato de que a lei seja reverenciada piedosamente, em tal sociedade, como um princípio divino, ou, por outra, como um comando derivado de um deus, a filosofia, como busca da verdade acerca das primeiras coisas e do que é bom e justo não de acordo com a legislação sagrada instituída, mas em si mesmo ou por natureza, implica ipso facto uma contestação do caráter supostamente divino da lei e um rechaço de toda a piedade tradicional ${ }^{27}$. Isso significa que a subversão perpetrada pela filosofia contra a autoridade da sociedade política é, em última análise, uma rebelião contra a autoridade divina, uma rebelião contra os deuses da cidade.

Strauss julga que tal conflito, manifestando a tensão profunda que vigora entre a filosofia e a autoridade divina, seria a oposição fundamental com a qual se confronta o pensamento humano e, levando em conta o fato de que a Bíblia representa a mais elevada expressão literária e documental do princípio da autoridade divina em nossa civilização, termina por considerar que a oposição entre a filosofia e o ensinamento bíblico (ou entre Atenas e Jerusalém, como ele às vezes gostava de dizer) seria a oposição mais radical de todas ${ }^{28}$. Tocamos aqui o cerne daquilo que Strauss chama de "problema teológico-político", problema que concerne à disputa entre a filosofia e a autoridade divina em torno da questão da orientação geral da vida humana e, por conseguinte, acerca de qual é, para o homem, a melhor forma de viver ${ }^{29}$. É o que aparece explicitamente na seguinte formulação efetuada por Strauss em Natural Right and History:

O homem não pode viver sem luz, sem orientação, sem conhecimento; somente
através do conhecimento do bem pode ele encontrar o bem de que carece. A
questão fundamental, portanto, é se os homens podem adquirir aquele
conhecimento do bem sem o qual eles não podem viver suas vidas, coletiva ou
individualmente, por meio dos esforços independentes de seus poderes naturais,
ou se eles, no que concerne àquele conhecimento, dependem da Revelação
Divina. Nenhuma alternativa é mais fundamental do que esta: orientação
humana ou orientação divina. A primeira possibilidade é característica da
filosofia, ou ciência, no sentido original do termo; a segunda alternativa é
apresentada pela Bíblia. Não é possível se esquivar do dilema por meio de
qualquer síntese ou harmonização. Pois tanto a filosofia quanto a Bíblia
proclamam algo como a única coisa necessária, como a única coisa que, em
última análise, conta, e a única coisa necessária proclamada pela Bíblia é o

${ }^{27} \mathrm{Cf}$. as seguintes afirmações de nosso autor em: "The Mutual Influence of Theology and Philosophy" (1979, p.111-112): "The philosophers transcend the dimension of divine codes altogether, the whole dimension of piety and pious obedience to a pre-given code. Instead they embark on a free quest for the beginnings, for the first things, for the principles."

${ }_{28}$ Tal é o tema explorado por Strauss no ensaio "Athens and Jerusalem", pertencente à coletânea Studies in Platonic Political Philosophy (1983, p.147-173).

${ }^{29}$ Ver TANGUAY (2003, p. 226-227); PANGLE (2006, p.27); MEIER (2006, p.6-7). 
oposto daquela proclamada pela filosofia: uma vida de amor obediente versus uma vida de livre compreensão ${ }^{30}$.

Para Strauss, a percepção do caráter conflituoso das relações entre a filosofia e a revelação divina (ou entre Atenas e Jerusalém), com o consequente entendimento de que o exercício da atividade filosófica é animado pela pretensão de subverter aquilo que representa essa revelação divina, já seria algo presente no próprio texto bíblico (principalmente naquilo que nos apresenta a narrativa do Gênesis), o que explicaria porque a proibição fundamental veiculada pela Bíblia é, em última análise, uma proibição contra a filosofia. É o que o filósofo pretende nos mostrar através da provocativa e instigante exegese dos primeiros capítulos do Gênesis levada a efeito no ensaio "Sobre a interpretação do Gênesis", publicado pelo periódico francês L'Homme ${ }^{31}$. De fato, na óptica straussiana elaborada no referido ensaio, a leitura atenta dos primeiros capítulos do Gêenesis nos mostraria que o interdito primevo estabelecido pela Bíblia é um interdito dirigido contra a filosofia - ou, por outra, um interdito dirigido contra aquilo que a filosofia representa, a saber, a pretensão do homem de alcançar um conhecimento autônomo do bem e do mal, ou do correto modo de vida, por meio da elaboração de uma cosmologia ou de uma compreensão puramente racional da natureza das coisas. A Bíblia condenaria tal pretensão por considerá-la como uma tentação ínsita à razão natural do homem e radicalmente contrária a fé, na medida em que em sua efetivação envolveria o rechaço daquele que é o ensinamento mais fundamental preconizado pela fé bíblica, a saber, a concepção de que o verdadeiro conhecimento do bem e do mal não pode ser alcançado pelo entendimento humano natural e independente, mas apenas por meio do concurso de um evento sobrenatural: a revelação divina. Em outras palavras, o que o texto bíblico do Gênesis nos ensinaria, por assim dizer, em suas filigranas, é que a fé exclui, antes de qualquer outra coisa, o princípio do conhecimento autônomo, e que, consequentemente, à luz do que preconiza a fé, o acesso do homem ao saber verdadeiro acerca modo correto de viver não pode se dar por meio das forças de seu próprio intelecto, mas tão somente graças à manifestação de um Deus misterioso e incompreensível, "o último e mais elevado tema da Bíblia” (STRAUSS, 1981, p.20). Isso significa, portanto, segundo Strauss, que há, no âmago da própria narrativa do Gênesis, o reconhecimento de uma oposição essencial e não meramente acidental entre a

30 Cf. STRAUSS, 1971, p.74. Ver também, mais uma vez, o que o filósofo diz em "Reason and Revelation (1948)" (apud MEIER, 2006, p.149).

${ }^{31}$ Cf. "On the Interpretation of Genesis" (1981, p.5-20). Há uma versão nossa, para o vernáculo, deste trabalho straussiano. Cf. "Sobre a interpretação do Gênesis". Pensar- Revista Eletrônica da FAJE (2014, p.297-323). 
fé (que exige uma vida de obediência à revelação) e a razão (que pressupõe a livre busca de um conhecimento autônomo), uma oposição que não poderia ser resolvida por nenhum tipo de "síntese feliz, superior aos elementos isolados", o que desemboca, enfim, na constatação de que o que o ensinamento bíblico pretende nos fornecer, desde os seus momentos iniciais, é, em última análise, uma "alternativa à tentação da filosofia" (STRAUSS, 1981, p.19).

O que foi acima explicitado nos mostra de que maneira, segundo Strauss, a filosofia aparece realmente como uma prática politicamente problemática para a cidade e para a ordem moral nela presente, efetivando-se como uma atividade intelectual que, pressupondo a assunção de uma atitude polêmica e iconoclasta diante daquilo que é o esteio da estrutura comunitária a lei divina e os valores por ela preconizados - contém em si algo de atópico e mesmo de perigoso para a sociedade política. Não é nenhuma surpresa, portanto, que a sociedade política veja, a princípio, a filosofia com maus olhos, encarando-a com suspeita e manifestando contra os que se dedicam ao seu exercício uma postura francamente hostil e mesmo violenta. Veremos a seguir como Strauss, refletindo sobre tal problema, pensou a questão do recurso ao esoterismo como uma necessidade retórica no contexto da filosofia tradicional, chegando à identificação, no desenvolvimento dessa reflexão, da existência de uma relação intrínseca entre o fenômeno do esoterismo e a gênese da filosofia política.

\section{A emergência da filosofia política: perseguição, literatura esotérica e apresentação pública da filosofia}

Como se sabe, a questão das relações conflituosas entre filosofia e sociedade constitui o objeto privilegiado de uma das obras mais conhecidas de Strauss, Persecution and the Art of Writing (1992a) ${ }^{32}$. Com efeito, nessa obra, Strauss pretende elaborar uma "sociologia da filosofia" (sociology of philosophy), entendida como uma disciplina específica, pertencente ao grande campo constituído pela "sociologia do conhecimento" (sociology of knowledge). Como esclarece o autor, apesar da proximidade entre essas duas abordagens, há, porém, entre elas, uma diferença fundamental e significativa, que consiste, grosso modo, no seguinte: enquanto a "sociologia do conhecimento" parte do pressuposto da existência de um acordo tácito ou de uma harmonia implícita entre o pensamento (i. e., a filosofia e a ciência) e a esfera das instituições

32 Como esclarece Strauss no prefácio da obra (p.5): "These essays are here collected into one volume primarily with a view to the fact that they all deal with one problem: the problem of the relation between philosophy and politics." 
sociais e políticas, a "sociologia da filosofia" se assenta no princípio contrário, na medida em que levanta a suspeita de que as relações do pensamento com as instituições sociais e políticas não são pacíficas ou tranquilas, mas, antes, radicalmente problemáticas. A consequência que resulta da assunção desse ponto de vista é a concepção de que a filosofia não se reduz a uma ideologia ou a um mero instrumento político de um regime e de que os filósofos constituem, portanto, um grupo humano atópico, sui generis ou à parte, de forma que aquilo que os aproxima intelectualmente é sempre mais importante do que aquilo que os liga a uma classe ou estrutura social e coletiva qualquer (STRAUSS, 1992a, p.7-8; 1971, p.143).

Na óptica de Strauss, isso significa que os grandes pensadores não são nunca homens de seu próprio tempo ou meros rebentos da história, mas, ao contrário, homens que se definem contra o seu tempo (DRURY, 2005, p.18). Strauss deliberadamente subverte, com essa formulação, a posição historicista tradicional - que encontrou em Hegel, Marx e Heidegger, como se sabe, seus mais fortes e portentosos expoentes -, posição segundo a qual o pensamento humano estaria irremediavelmente preso nas malhas da imanência histórica e dos condicionamentos sociais por ela produzidos, nada mais sendo do que a transposição dessa imanência na esfera noética dos conceitos e das ideias ${ }^{33}$. Segundo Strauss, a constatação da capacidade do pensamento humano de apreender e compreender as questões mais fundamentais, vale dizer, as questões perenes ou permanentes com as quais se confronta a nossa razão e que constituem, por isso, em toda parte e sempre, o estímulo originário da atividade reflexiva autêntica, manifestaria o poder do espírito humano de transcender aquilo que é historicamente dado e de captar, no âmago mesmo da temporalidade, algo de atemporal - fenômeno que representa, por si só, uma poderosa objeção contra a veracidade intrínseca da tese historicista acerca da historicidade constitutiva de todo pensamento ${ }^{34}$.

Pois bem, Strauss considera que o pensamento filosófico é capaz de se definir contra as instituições sociais e políticas, não se reduzindo a um mero produto histórico, porque, como vimos, o seu exercício envolve o desenvolvimento de um questionamento livre, subversivo e heterodoxo das crenças ou opiniões socialmente autorizadas, o que acaba por ofender a autoridade política instituída que se assenta sobre tais crenças ou opiniões. Ora, na visão straussiana, a resposta da sociedade política a essa ofensa perpetrada pela filosofia é, frequentemente, a perseguição. Para nosso autor,

${ }^{33}$ Acerca do significado filosófico do historicismo, cf. STRAUSS, 1971, p.9-34.

${ }^{34}$ Ver a problematização do historicismo levada a efeito por Strauss em Natural Right and History (1971, p.31-34). Cf. também, sobre isso, as explicações de PANGLE (2006, p.34-36). 
temos aí, sem dúvida, um fenômeno de certo modo ubíquo, que ocorre não apenas no contexto de organizações comunitárias tradicionais ou prémodernas, mas, também, no âmbito das próprias sociedades modernas e liberais. Strauss nos informa, nesse sentido, que a perseguição pode ser dura ou suave, ostensiva ou velada, apoiada no uso explícito da violência ou na prática do simples ostracismo social, mas que, de uma forma ou de outra, ela sempre se faz presente ${ }^{35}$. Sócrates constitui, como é fácil ver, o caso paradigmático no que diz respeito à questão - mas não é, de forma alguma, o caso único. (STRAUSS, 1992a, p.32-33). Ora, Strauss considera que o fenômeno da perseguição teria originado, no mundo antigo e medieval, a necessidade da elaboração de uma técnica literária sofisticada e diferenciada de comunicação do pensamento filosófico, no intuito de neutralizar o impacto potencialmente negativo dessa comunicação sobre a ordem cívica e, com isso, dirimir, em parte, o conflito vigente entre a filosofia e a sociedade. Tal técnica literária, na perspectiva straussiana, é justamente a escrita esotérica, entendida como uma estratégia retórica e discursiva empregada pelos autores clássicos e medievais para veicular seus ensinamentos heterodoxos de forma críptica e disfarçada, sem ofender de maneira flagrante o ordenamento social vigente e as crenças morais e religiosas que o alicerçam. Segundo Strauss, esse procedimento literário teria sido inteiramente esquecido, no transcorrer dos séculos, pelos estudiosos e eruditos que se dedicam à história do pensamento e das ideias (graças, sem dúvida, a certos triunfos alcançados pela modernidade) ${ }^{36}$; não obstante, ele cumpriu, conforme pensa nosso autor, um papel inequivocamente decisivo no contexto social e intelectual pré-moderno, na medida em que a sua utilização constituiu o principal recurso de que se valiam os pensadores antigos e medievais em seu trabalho de comunicação com a comunidade política. Grosso modo, a característica essencial desse tipo de literatura estaria, do ponto de vista straussiano, no uso inteligente da "escrita nas entrelinhas" (writing between the lines), vale dizer, daquela forma de escrita deliberadamente ambígua, capaz de comunicar, de forma velada e sob a fachada de um texto aparentemente inofensivo, os ensinamentos heterodoxos (e, portanto, mais perigosos e potencialmente subversivos) de um autor. Nas palavras de Strauss:

35 Como observa acertadamente Drury: "For Strauss, the conflict does not apply only to those societies that cannot tolerate the freedom to dissent. Strauss is quite earnest about the permanence and universality of the conflict" (2005, p.19).

${ }^{36}$ Strauss se refere, por isso, à literatura esotérica como uma "esquecida forma de escrever" (a forgotten kind of writing). Ver, neste sentido, o ensaio consagrado à questão do esoterismo em What Is Political Philosophy?, intitulado justamente "On a Forgotten Kind of Writing" (apud STRAUSS, 1988, p.221-232). 
A expressão 'escrever nas entrelinhas' indica o assunto deste artigo. Pois a influência da perseguição sobre a literatura é precisamente aquilo que compele todos os escritores que sustentam visões heterodoxas a desenvolver uma peculiar técnica de escrita, a técnica em que pensamos quando falamos de escrever nas entrelinhas [...] perseguição, portanto, dá origem a uma peculiar técnica de escrita e, por esse meio, a um peculiar tipo de literatura, no qual a verdade sobre todas as coisas cruciais é apresentada exclusivamente nas entrelinhas. Essa literatura é dirigida não a todos os leitores, mas apenas aos leitores confiáveis e inteligentes. Ela tem todas as vantagens da comunicação privada, sem ter sua maior desvantagem - o fato de alcançar apenas os conhecidos do escritor. Ela tem todas as vantagens da comunicação pública, sem ter sua maior desvantagem - a punição capital para o autor. Mas como pode um homem realizar o milagre de falar, em uma publicação, para uma minoria, enquanto permanece silencioso para a maioria de seus leitores? $\mathrm{O}$ fato que torna essa literatura possível pode ser expresso no axioma segundo o qual homens que não pensam são leitores descuidados, ao passo que somente homens pensantes são leitores cuidadosos (1992a, p.24-25).

O exercício da arte do esoterismo envolve, assim, a elaboração de uma escrita sagaz e maliciosa, que se vale deliberadamente da ambivalência, no intuito de camuflar, nas suas entrelinhas, as visões heterodoxas e polêmicas que um autor pretende destinar apenas aos leitores realmente capazes de reflexão. O resultado desse procedimento é a confecção de livros de natureza complexa, comportando duas dimensões fundamentais: uma, de caráter exotérico e vinculada à letra do texto, que é acessível a qualquer leitor e cujos enunciados se coadunam inteiramente com as crenças oficialmente admitidas pela cidade; outra, de caráter esotérico e que se insinua nas entrelinhas do texto, veiculando, de modo camuflado e sub-reptício, os ensinamentos potencialmente subversivos de um autor que, por colocarem em risco as crenças oficialmente admitidas pela cidade, devem ser assimilados apenas pelos leitores intelectualmente mais preparados e cuidadosos (STRAUSS, 1992a, p.32-36). Nesse sentido, pode-se dizer que a prática da escrita esotérica se efetiva como um sofisticado ardil retórico, por meio do qual o filósofo logra dissimular seus verdadeiros pensamentos, ocultando-os sob o envoltório de um discurso exotérico e de caráter moralmente edificante, de modo a não agredir de forma aberta as opiniões morais e religiosas endossadas pela sociedade ${ }^{37}$.

Como observou Pangle, Strauss via sua redescoberta da escrita esotérica como uma das contribuições mais revolucionárias de seus estudos para o campo da "sociologia do conhecimento", na medida em que, para ele, graças a esse elemento uma luz completamente nova ou diferente pôde ser lançada sobre o problema das relações entre os grandes autores do passado e o

${ }^{37}$ Cf. TANGUAY (2003, p.115-116); DRURY (2005, p.19); PANGLE (2006, p.56-58). 
contexto político e social em que viveram. ${ }^{38}$ É preciso lembrar, porém, que o tema do esoterismo foi um dos pontos mais controversos e polêmicos dos trabalhos de Strauss, provocando o aparecimento das acusações de elitismo e imoralismo que foram lançadas contra tais trabalhos por críticos que viram aí um mero subterfúgio para legitimar o uso da mentira como prática política ordinária ${ }^{39}$. Seja como for, levando em conta o que se disse acima, percebe-se, pois, que, de acordo com a análise straussiana, o recurso à técnica literária do esoterismo se confunde, em última análise, com elaboração de uma forma de comunicação de caráter profundamente irônico, se por ironia entendemos, na esteira do que afirma o próprio Strauss, a arte de falar diferentemente para diferentes tipos de público ${ }^{40}$. Tal procedimento irônico, constitutivo da escrita esotérica praticada pelos autores antigos e medievais e cuja realização envolve necessariamente o recurso à arte de se falar diferentemente para diferentes tipos de público, se justificava, para tais autores, por razões de natureza política e tinha como pretensão básica, de um modo geral, como foi dito acima, apaziguar o conflito entre a filosofia e a sociedade, mediante uma apresentação edulcorada e exotérica do ensinamento filosófico. Ora, conforme Strauss - e este é um ponto crucial, para o qual gostaríamos, agora, de chamar a atenção o uso da escrita esotérica assim entendida é um elemento essencial para se compreender o significado da filosofia política em sua expressão original; na verdade, para o nosso autor, o uso da escrita esotérica assim entendida se identifica com a própria filosofia política em sua expressão original. É o que Strauss afirma de maneira explícita, nos seguintes termos:

$\mathrm{O}$ ensinamento exotérico era requerido para proteger a filosofia. Ele era a couraça com que a filosofia tinha de aparecer. Ele era necessário por razões políticas. Ele era a forma pela qual a filosofia tornou-se visível. Ele era o aspecto político da filosofia. Ele era a 'filosofia política' (1992a, p.18).

Explorando a ideia de que a filosofia política consistiu, a princípio, essencialmente, no trabalho de elaboração de uma versão exotérica da filosofia,

38 "Strauss's rediscovering of esoteric writing is intended by him to be his revolutionary contribution to the 'sociology of knowledge' [...] By the same token, this rediscovery is the core of Strauss's revolutionary suggestion about the proper understanding of the relation to their historical contexts of those thinkers who employ such writing" (PANGLE, 2006, p.59).

39 É o que observam Zuckert, C.; Zuckert, M. (2006, p.42): "Nothing has prove more controversial in Strauss's own work than his analyses of esotericism, of secret writing and secret teaching. Strauss's suggestion that earlier thinkers did not state all their views openly has led to accusations that he immorally endorsed lying as well as elitism."

${ }^{40}$ Cf. STRAUSS (1992b, p.51). Ver também as seguintes asserções do filósofo, contidas em Thoughts on Machiavelli (1992c, p.40): "In a deliberate self-contradiction an author says incompatible things or, more generally stated, different things about the same subject to different people, and in some cases to the same people in different stages of their understanding. But to speak differently to different people may be said to be irony in the primary sense of the word." 
Strauss desembocou naturalmente na concepção de que a filosofia política foi, pois, originalmente, não tanto a abordagem filosófica das coisas políticas quanto a apresentação política da filosofia, ou, por outra, a apresentação pública ou popular da filosofia, a apresentação da filosofia, enfim, do ponto de vista da cidade, objetivando, como dissemos acima, a consecução do apaziguamento das relações conflituosas ou antagônicas da filosofia com o mundo da pólis. Nas palavras de nosso autor:

O adjetivo "política" na expressão "filosofia política" designa não tanto o assunto quanto a forma de abordagem; deste ponto de vista, "filosofia política" significa primariamente não o tratamento filosófico da política, mas o tratamento político ou popular da filosofia, a introdução política à filosofia [...] (STRAUSS, 1988, p.93).

De acordo com este ponto de vista, a filosofia política foi, pois, antes de tudo, em suas origens, a aparência pública assumida pela filosofia, vale dizer, a aparência mais edificante, edulcorada e menos subversiva adquirida pela filosofia quando esta se viu obrigada a abandonar sua postura inicial de caráter puramente teorético e a se introduzir no plano da cidade e de seus negócios, no intuito de acomodar a atividade filosófica à realidade da vida política ordinária ${ }^{41}$. Ora, acomodar a atividade filosófica à realidade da vida política ordinária significa, antes de mais nada, para Strauss, fazer com que a filosofia reconheça a multidão de não-filósofos que habita a cidade e se defenda diante do tribunal cívico instaurado por essa multidão, disfarçando sua natureza mais subversiva, atópica e perturbadora. Na medida, porém, que a multidão ignora a filosofia e os procedimentos que lhe são próprios, o filósofo, para se fazer compreensível, deve, pois, falar a linguagem da pólis, a linguagem da caverna, dialogando com os não-filósofos no intuito de persuadi-los de que a prática da filosofia não é um comportamento perverso ou politicamente prejudicial, mas, antes, uma ocupação nobre e permissível, capaz de contribuir para a elevação moral do homem e para o bem da comunidade política (STRAUSS, 1988, p.93-94). Donde se chega à conclusão de que a filosofia política nada mais é, pois, no âmbito dessa formulação, do que o exercício retórico próprio do filósofo, exercício retórico que se consuma como um discurso apologético e persuasivo dirigido pelo filósofo à cidade e àqueles que a habitam a fim de justificar politicamente suas atividades, ocultando

${ }^{41}$ Como explicam Zuckert, C.; Zuckert, M. (apud COPPENS; JANSSENS; Y. YOMTOV, 2014, p.19): "La philosophie politique est le visage que la philosophie presente à l'existence humaine ordinaire, non philosophique. Elle est une version bien coiffée et apprêtée de la philosophie, une présentation de celleci telle que dans sa présence publique elle émousse et estompe la tension dans laquelle elle se tient avec les opinions constitutives de la cité." 
prudentemente a dimensão mais polêmica e perturbadora de sua prática intelectual.

Pois bem, Strauss julga que, graças à utilização da filosofia política assim compreendida, os filósofos antigos e medievais lograram transmitir seus pensamentos de uma forma críptica e disfarçada, alcançando a consecução de três importantes objetivos: 1) em primeiro lugar, proteger os filósofos de eventuais perseguições políticas; 2) em segundo lugar, proteger a sociedade dos efeitos nocivos e devastadores da crítica filosófica; 3) finalmente, em terceiro lugar, atrair potenciais talentos filosóficos para a causa da filosofia (STRAUSS, 1992a, p.32-36). Acreditamos que o segundo ponto é de extrema importância para uma compreensão mais consistente da questão do esoterismo em Strauss, pois ele nos mostra claramente que a necessidade do uso da escrita esotérica pelo filósofo se explica, para esse autor, não apenas porque o filósofo precisa ser cauteloso e se precaver contra eventuais inimigos que se sintam ofendidos pelo exercício de suas críticas e problematizações, mas também porque a filosofia não é uma prática intelectual inofensiva e desprovida de consequências sociais, mas, antes, uma atividade politicamente subversiva e perigosa, que ameaça, com seus questionamentos heterodoxos, sabotar as opiniões sobre as quais repousa a autoridade da comunidade política. ${ }^{42} \mathrm{Em}$ outras palavras, a necessidade do esoterismo deriva da própria natureza polêmica e politicamente problemática da filosofia. Em uma passagem crucial de What Is Political Philosophy? Strauss explicita muito bem esse aspecto de seu pensamento, articulando os dados acima mencionados da seguinte maneira:

A filosofia ou a ciência, as mais altas atividades do homem, são a tentativa de substituir opiniões sobre "todas as coisas" pelo conhecimento de "todas as coisas"; mas a opinião é o elemento da sociedade; a filosofia ou a ciência são, portanto, a tentativa de dissolver o elemento no qual a sociedade respira e, por conseguinte, uma ameaça à sociedade. Por isso, a filosofia ou a ciência devem permanecer o privilégio de uma pequena minoria, e os filósofos ou cientistas devem respeitar as opiniões sobre as quais a sociedade repousa. Respeitar opiniões é algo inteiramente diferente de aceitar as opiniões como verdadeiras. Filósofos ou cientistas que assumem essa visão sobre a relação da filosofia ou ciência com a sociedade são levados a empregar uma peculiar maneira de escrever que os habilitaria a revelar o que eles observam como a verdade para poucos, sem colocar em risco o comprometimento incondicional da maioria com as opiniões sobre as quais a sociedade repousa. Eles distinguirão entre o verdadeiro ensinamento, como ensinamento esotérico, e o ensinamento socialmente útil, como o ensinamento exotérico; enquanto o ensinamento exotérico pretende ser acessível a qualquer leitor, o ensinamento esotérico só se revela aos leitores cuidadosos e bem treinados, após um longo e concentrado estudo (1988, p. 221-222).

${ }^{42}$ Sobre isso, ver TANGUAY (2003, p.118-119); DRURY (2005, p. 19-20); ZUCKERT, C.; ZUCKERT, M. (2006, p.43-44). 
O elemento fundamental que justifica o uso da literatura esotérica pelo filósofo é, pois, como se vê pela passagem citada, a constatação da periculosidade intrínseca da filosofia, constatação derivada do reconhecimento da radical problematicidade política da atividade filosófica, fenômeno que resulta, por sua vez, do fato de que a filosofia não apenas agride, mas também coloca realmente em perigo, com seus questionamentos incessantes e corrosivos, a sociedade e suas opiniões autorizadas, ("philosophy endangers society", diz Strauss, na versão original do trecho acima citado) (PANGLE, 2006, p.54-56). Para Strauss, tal fenômeno é, de certa forma, um evento universal, pois, enquanto a filosofia é e sempre será, desde que ela mantenha fidelidade à sua natureza, a tentativa subversiva de transformar opiniões em conhecimento, rechaçando toda autoridade instituída, qualquer ordenamento social, por seu turno, por mais liberal que seja, sempre se fundamentará em determinadas opiniões políticas e morais básicas que, por garantirem a sua permanência ou perpetuação, exigem um "comprometimento incondicional" (unqualified commitment) daqueles que a elas aderem ${ }^{43}$. Como o filósofo reconhece sua dependência para com a sociedade política (STRAUSS, 1971, p.152), admitindo que "toda vida humana é vida em comum, ou, mais exatamente, vida política" (STRAUSS, 1988, p.92-93), ele não tem nenhum interesse em sabotar publicamente as opiniões que sustentam a ordem social vigente, o que o leva a proceder com extrema cautela na comunicação ou veiculação de seus pensamentos. Daí o uso, de sua parte, da arte do esoterismo como procedimento imprescindível para efetuar a acomodação de sua atividade intelectual às estruturas da cidade, no intuito de preservar, por um lado, a cidade dos ataques especulativos da filosofia, e, por outro, a filosofia das perseguições políticas desencadeadas pela cidade ${ }^{44}$.

${ }^{43}$ Cf. STRAUSS, 1988, p.222. Explorando a visão straussiana da existência de uma oposição entre a exigência (inerente à economia da vida social) de respeito às opiniões políticas e morais instituídas e a prática da filosofia como exercício do questionamento intransigente, envolvendo, por conseguinte, a rejeição da autoridade instituída, Meier nos fornece os seguintes esclarecimentos: "The philosophical life has its raison d'etre in the fact that it is grounded in unreserved questioning and stops at no answer that owes its authentication to an authority. The vital element of society is made up, by contrast, of opinions and faith; society draws its power from the fact that its basic principles are held to be true, its norms followed without question, its taboos regarded as matters of course, its institutions met with broad trust. Instead of doubt and suspension of judgement, society requires resolute action and the courageous engagement, if not the enthusiasm of its citizens for the common good, which, however, remains a particular and partial good. The well-ordered political community is built on identification, on devotion and agreement, whereas the philosophical eros is 'completely at home' nowhere but 'in his homelessness'" (2006, p.99).

${ }_{44}$ Meier explicita de forma magistral esses elementos presentes nas reflexões straussianas acerca do esoterismo da seguinte forma: "The grounds that induced the philosophers to write exoteric-esoterically, however, go far beyond political considerations of censorship and persecution. They arise from the insight into the insuperable tension that exists between the political community and philosophy. The 
Percebe-se, de acordo com os elementos presentes na reflexão levada a efeito por Strauss, que o esoterismo praticado pelos autores clássicos e medievais funda-se numa compreensão eminentemente prudencial do comportamento da filosofia em relação à cidade, compreensão que pressupõe a observação de uma certa cautela no trabalho de comunicação do ensinamento filosófico, sob o pressuposto de que "existem verdades básicas que não deveriam ser pronunciadas em público por nenhum homem decente" (STRAUSS, 1992a, p.36). Em outras palavras, mesmo que a filosofia seja, por sua própria natureza, uma atividade essencialmente perigosa, ímpia e subversiva, ela não deve escandalizar a consciência comum, atacando abertamente as crenças morais e religiosas que servem de esteio à sociedade, pois tal ato colocaria em risco a ordem política estabelecida. Como se pode ver, o elemento central para o qual a reflexão de Strauss pretende chamar nossa atenção aqui é o fato de que o filósofo, como cidadão, possui responsabilidades cívicas inquestionáveis e, possuindo responsabilidades cívicas inquestionáveis, não pode deixar de reconhecer "as exigências legítimas da sociedade" em que vive no que diz respeito à preservação das opiniões fundamentais ou constitutivas que sustentam seu funcionamento, razão pela qual ele ocultará seus pensamentos politicamente perigosos e heterodoxos, propagando, para o grande público, apenas aqueles ensinamentos que considera como socialmente úteis e moralmente salutares ${ }^{45}$.

Reconhecendo a sabedoria desse comportamento prudencial, Strauss considerará, assim, que, não obstante a atividade filosófica, como exercício livre e independente do pensamento, seja o oposto de toda sobriedade vulgar, aproximando-se, antes, da loucura, na medida em que sua atualização envolve a coragem e mesmo a impudência de um questionamento onímodo e universal, que não se detém diante de nada, o filósofo deve ter sempre certo

exoteric-esoteric double-face is the attempt to protect philosophers from society and nonphilosophers from philosophy. It is destined to take account of the necessities of politics on the one hand and of the requirements of the philosophical life on the other. The art of careful writing is therefore the expression of an equally fundamental and comprehensive reflection on politics, philosophy, and the nature of the philosopher" (2006, p.64-65).

${ }^{45}$ Sobre o uso do ensinamento exotérico como prática derivada da responsabilidade cívica do filósofo e de seu reconhecimento das "exigências legítimas da sociedade", ver o que Strauss afirma em "Reason and Revelation (1948)": "If the opinion is the element of political life, philosophy which questions opinions as such, dissolves the very element of social life: philosophy is essentially subversive (corrupting the young). From the point of view of philosophy, this is no objetction to philosophy, since quest for the truth is infinitely more importante than political life: philosophizing is learning to die. Still, the philosopher has to meet the legitimate claims of society or to shoulder his own responsibility as a citizen. He does this by refraining from publicily teaching what he considers the truth in so far as the truth could become dangerous to society. He hides his true teaching behind a socially usefull exoteric teaching" (apud MEIER, 2006, p.146). 
comedimento na comunicação de seus ensinamentos. Dito de outra maneira, embora, para Strauss, a moderação não seja uma virtude do pensamento (como vimos, segundo nosso autor, o pensamento deve ser destemido [fearless] e impudente [shameless]), ela é o princípio que deve regular a enunciação pública do discurso filosófico ${ }^{46}$.

Avançando nesta linha de reflexão, Strauss parece considerar, assim, que a filosofia política é, antes de tudo, o exercício da moderação no plano discursivo ou, por outra, a expressão moderada de pensamentos que, por sua ousadia e destemor intelectuais intrínsecos, não conhecem como tais nenhuma medida ou moderação. Isso significa, de acordo com a reflexão straussiana, que a filosofia deve ser sempre circunspecta em sua apresentação pública, mantendo-se, no que possui de mais essencial, como uma atividade essencialmente secreta e de natureza contemplativa que, como tal, restringe-se discretamente àqueles poucos que são dotados das qualificações espirituais necessárias para exercer o duro e perigoso empreendimento intelectual requerido pela busca intransigente da verdade das coisas. Em outras palavras, a concepção proposta por Strauss é que se a filosofia deve ser subversiva no plano cognitivo e reflexivo, na medida em que sua atividade envolve necessariamente, como vimos, a subversão de toda autoridade instituída, ela não pode deixar de ser reservada em sua comunicação, procurando sempre se adequar aos valores e às crenças vigentes em uma determinada organização social. Resulta daí, para Strauss, a atitude essencialmente conservadora que deve ser assumida pelo filósofo no que diz respeito ao comportamento político e social: o filósofo, de fato, justamente por saber dos tremendos riscos sociais inerentes ao seu questionamento intransigente de tudo, deve reservar seus ensinamentos heterodoxos para aqueles poucos capazes de realmente compreendê-los, procurando respeitar, em consequência, no plano público, as opiniões autorizadas fundamentais que asseguram um determinado ordenamento político, o que, nos ensina oportunamente Strauss, é algo completamente diferente de tomar ou aceitar essas opiniões como intrinsecamente verdadeiras ${ }^{47}$. Ora, respeitar as opiniões socialmente autorizadas, mesmo não as considerando verdadeiras, equivale a aprender a dissimular os próprios pensamentos, procedimento que, como pudemos ver anteriormente, se encontra no cerne mesmo do ardil irônico que é levado a efeito no exercício da arte literária do esoterismo. O conservadorismo adotado pelo filósofo é, portanto, neste sentido, um conservadorismo exotérico ou de

\footnotetext{
46 Nos termos de Strauss: "[...] moderation is not a virtue of thought [...] But moderation is a virtue controlling the philosopher's speech" (1988, p.32).

47 Ver, novamente, a passagem crucial de What Is Political Philosophy? (1988, p.221-222).
} 
caráter estritamente tático e político, fundado em uma adesão externa à ordem vigente, e não um conservadorismo filosófico, de vez que, na formulação de Strauss, a filosofia pressupõe, por sua própria natureza questionadora e radicalmente problematizante, a recusa de toda autoridade, o que a impede, por conseguinte, de ser verdadeiramente conservadora ${ }^{48}$. Trata-se, assim, de reconhecer que, embora o radicalismo seja um elemento essencial da prática filosófica, ele não é, muitas vezes, a postura mais razoável a ser adotada no plano político concreto, porquanto nesse plano a preservação da tradição e de certa estabilidade social aparece, com frequência, como uma necessidade política inquestionável. Pode-se dizer, para arrematar toda essa análise, que a grande façanha realizada pelos escritos de Strauss foi a de nos ensinar como combinar o radicalismo reflexivo próprio da atividade filosófica com o conservadorismo no terreno político, apresentando-nos um pensamento irônico e sofisticado que, tal como os modelos tradicionais que o inspiraram, visa à sobriedade e à moderação, escapando do fanatismo e das paixões ideológicas que tantos estragos produziram ao longo da história ${ }^{49}$.

\section{Referências}

BLOOM, A. “Leo Strauss: September 20, 1889 - October 18, 1973”. In: Political Theory, v. 2, no. 4, p.372-392, 1974.

DRURY, S. The Political Ideas of Leo Strauss. Updated Edition. Lexington: Palgrave Macmillan, 2005 (1987).

FERRY, L. Philosophie politique I. Le droit: la nouvelle querelle des anciens et des modernes. Paris: PUF, 1999.

48 Sobre a rejeição da autoridade como elemento característico da atividade filosófica, cf. também STRAUSS (1971, p.92).

49 Seguimos aqui, em nossas considerações finais, as excelentes observações desenvolvidas por Sedeyn acerca do uso do conservadorismo em Strauss. Diz-nos esse autor:"Mais si les philosophes politiques classiques, et Strauss, sont effectivement conservateurs en politique, cela ne signifie pas que la philosophie qu'ils pratiquent puisse être 'conservatrice'. II serait absurde d'être conservateur en philosophie parce que la philosophiene ne reconnaît en tant que telle aucune autorité existente, qu'elle soit politique ou religieuse ou traditionelle: le philosophe cherche le vrai et le vrai bien, qui doivent être universels, et donc hors du temps [...] Strauss montre ainsi par son œuvre combien il est possible de combiner um 'extrémisme' philosophique total, ou um 'radicalisme' dans l'exigence de dépasser la sphère de l'opinion qui est nécessaire à la recherche de la verité, et un conservatisme inteligente et non réactif en politique. Radicalisme en philosophie, conservatisme en politique. Socrate, Platon et Aristote lui avaient ouvert la voie" (apud STRAUSS, 2005, p.59-60). Levando em conta esses elementos, que apontam, mais uma vez, para a concepção straussiana do caráter intrinsecamente subversivo da filosofia em face de toda autoridade, permitimo-nos discordar, aqui, de Ménissier, para quem haveria, em Strauss, um conservadorismo propriamente "filosófico" (2009, p.873-893). 
MEIER, H. Leo Strauss and the Theologico-Political Problem. Cambridge: Cambridge University Press, 2006.

MÉNISSIER, T. "Leo Strauss, filiation néoconservatrice ou conservatisme philosophique ?”. In : Revue française de science politique, v. 59, p.873-893, 2009.

OLIVEIRA, R. R. "Leo Strauss, a filosofia e o problema teológico-político". In: CARDOSO, D. (org.). Pensadores do século XX. São Paulo: Edições Loyola, Paulus, 2012, p.23-42.

PANGLE, T. Leo Strauss. An Introduction to his Thought and Intellectual Legacy. Baltimore, Maryland: The Johns Hopkins, 2006.

SEDEYN, O. "Présentation". In: L. STRAUSS, La cité et l'homme. Présentation et traduction d'Olivier Sedeyn. Paris: Le Livre de Poche, 2005, p.5-60.

STRAUSS, L. "Reason and Revelation (1948)". In: MEIER, H. Leo Strauss and the Theologico-Political Problem. Cambridge: Cambridge University Press, 2006.

1971 (1953). . Natural Right and History. Chicago: The University of Chicago Press,

. "The Mutual Influence of Theology and Philosophy". In: The Independent Journal of Philosophy, v.3, p.111-118, 1979.

. “On the Interpretation of Genesis”. In: L’Homme, tome 21 (1981) 1, p.5-20. Versão em português: 'Sobre a interpretação do Gênesis'. Tradução de autor. Pensar-Revista Eletrônica da FAJE, vol. 5, no. 2 (2014) 297-323.

. Studies in Platonic Political Philosophy. Chicago: The University of Chicago Press, 1983.

What is Political Philosophy? And Other Studies. Chicago: The University of Chicago Press, 1988 (1959).

. Liberalism Ancient and Modern. Chicago: The University of Chicago Press, 1989 (1968).

. An Introduction to Political Philosophy. Ten Essays by Leo Strauss. Edited with an introduction by Hilail Gildin. Detroit: Wayne State University Press, 1989.

. Persecution and The Art of Writing. Chicago: The University of Chicago Press, 1992a (1952). (1964).

. The City and Man. Chicago: The University of Chicago Press, 1992b 
. Thoughts on Machiavelli. Chicago: The University of Chicago Press, 1992c (1958).

. Philosophy and Law. Contributions to the understanding of Maimonides and his predecessors. Translated with an introduction by Eve Adler. Albany: State University of New York Press, 1995 $338,1996$. "How To Study Medieval Philosophy". Interpretation, v. 23, n.3, p.319. On Tyranny. Corrected and expanded edition. Including the StraussKojève correspondence. Chicago: The University of Chicago Press, 2013 (1961).

TANGUAY, D. Leo Strauss: une biographie intellectuelle. Paris: Bernard Grasset, 2003.

ZUCKERT, C.; ZUCKERT, M. The Truth about Leo Strauss. Political Philosophy and American Democracy. Chicago: The University of Chicago Press, 2006.

. "Leo Strauss et le problème de la philosophie politique". In:

COPPENS, F.; JANSSENS, D.; YOMTOV, Y. (org.). Leo Strauss. À quoi sert la philosophie politique. Paris: PUF, 2014, p.15-24.

E-mail: richardromeiro@hotmail.com

Recebido: $10 / 2016$

Aprovado: 09/2016 